\title{
Expression of neuropilin-1 on in vivo induced regulatory $\mathrm{T}$ cells
}

\author{
Christopher J Nirsch1 ${ }^{1,2^{*}}$, Christina Ceccato ${ }^{1,2}$, Angela Alme ${ }^{1,2}$, Brian Francica ${ }^{1,2}$, Charles G Drake ${ }^{1,2,3}$ \\ From Society for Immunotherapy of Cancer 28th Annual Meeting \\ National Harbor, MD, USA. 8-10 November 2013
}

One of the current questions surrounding CD4 T regulatory cells (Tregs) is the role of natural and induced Tregs in tumor tolerance. Natural Tregs are CD4 T cells that leave the thymus expressing FoxP3 and displaying regulatory potential. Induced Tregs leave the thymus as a naïve CD4 T cell (FoxP3-), but are skewed by conditions encountered during antigen recognition to express FoxP3 and gain regulatory function. Several groups have recently suggested that Neuropilin-1 may be a suitable marker for natural Tregs. To examine the ability of neuropilin- 1 to identify natural versus in vivo induced Tregs, we bred a CD4 $\mathrm{T}$ cell receptor transgenic mouse specific for HA (6.5) onto a Rag-2 -/- background. The resultant 6.5 Rag -/- mice have no Tregs (as defined by FoxP3 expression), as has been noted for other TCR transgenic models, and express no neuropilin-1 (or CD25) prior to manipulation. To test whether neuropilin-1 was expressed on in vivo induced Tregs we performed a series of adoptive transfer studies into A) non-transgenic hosts, followed by low dose i.v. HA peptide administration B) self antigen expressing animals (C3-HAlow) or C) tumor antigen expressing mice (established HA expressing 4T1 mammary carcinomas). Our data show that in vivo induced Tregs clearly express neuropilin-1 under these various conditions. Furthermore, neuropilin-1 expression was found on both FoxP3+ and FoxP3- populations in all three models of in vivo induced Tregs, suggesting that neuropilin-1 is expressed on activated cells. Consistent with this notion, we found that neuropilin-1 was strongly upregulated within the first several divisions on 6.5 CD4 T cells when adoptively transferred into a host receiving HA expressing Vaccinia Virus. CD25 expression was more closely associated with FoxP3 expression than neuropilin-1: In the low dose i.v. peptide model, neuropilin-1+ CD25+ 6.5 CD4 T cells were significantly enriched for FoxP3 and Helios expression, whereas

Oncology, Johns Hopkins School of Medicine, Baltimore, MD, USA Full list of author information is available at the end of the article neuropilin-1+ CD25- 6.5 CD4 T cells were not. Tumor induced 6.5 CD4 Tregs also expressed low levels of neuropilin-1, even though the majority of $6.5 \mathrm{CD} 4 \mathrm{~T}$ cells were not induced to express FoxP3 by tumor antigen recognition. These data strongly support the notion that neuropilin-1 is not a specific marker of natural Tregs in mice, and further suggest that the majority of FoxP3+ TILS are likely natural Tregs, rather than induced Tregs.

\section{Authors' details}

${ }^{1}$ Oncology, Johns Hopkins School of Medicine, Baltimore, MD, USA.

${ }^{2}$ Immunology, Johns Hopkins School of Medicine, Baltimore, MD, USA.

${ }^{3}$ Urology, Johns Hopkins School of Medicine, Baltimore, MD, USA.

Published: 7 November 2013

doi:10.1186/2051-1426-1-S1-P167

Cite this article as: Nirschl et al:: Expression of neuropilin-1 on in vivo induced regulatory T cells. Journal for ImmunoTherapy of Cancer 20131 (Suppl 1):P167.

Submit your next manuscript to BioMed Central and take full advantage of:

- Convenient online submission

- Thorough peer review

- No space constraints or color figure charges

- Immediate publication on acceptance

- Inclusion in PubMed, CAS, Scopus and Google Scholar

- Research which is freely available for redistribution
C Biomed Central

ㄷ 2013 Nirschl et al; licensee BioMed Central Ltd. This is an Open Access article distributed under the terms of the Creative Commons Attribution License (http://creativecommons.org/licenses/by/2.0), which permits unrestricted use, distribution, and reproduction in any medium, provided the original work is properly cited. 